\title{
World Trade and Investment Law in a Time of Crisis: Distribution, Development and Social Protection
}

\author{
David M. Trubek \\ University of Wisconsin Law School, dmtrubek@wisc.edu \\ Alvaro Santos \\ Georgetown University Law Center, asantos@law.georgetown.edu \\ Chantal Thomas \\ Cornell Law School
}

This paper can be downloaded free of charge from:

https://scholarship.law.georgetown.edu/facpub/2379

https://ssrn.com/abstract=3839021

David Trubek, Alvaro Santos \& Chantal Thomas, Introduction: World Trade and Investment Law in a Time of Crisis: Distribution, Development and Social Protection, in World Trade and Investment Law Reimagined: A Progressive Agenda for an Inclusive Globalization 1-28 (Alvaro Santos, Chantal Thomas \& David Trubek eds., London: Anthem Press 2019).

This open-access article is brought to you by the Georgetown Law Library. Posted with permission of the author. Follow this and additional works at: https://scholarship.law.georgetown.edu/facpub

Part of the International Trade Law Commons, and the Law and Economics Commons 


\title{
WORLD TRADE AND INVESTMENT LAW IN A TIME OF CRISIS: DISTRIBUTION, DEVELOPMENT AND SOCIAL PROTECTION
}

\author{
David Trubek, Alvaro Santos and Chantal Thomas
}

\author{
Introduction to \\ World Trade and Investment Law Reimagined: A Progressive Agenda for an Inclusive Globalization \\ Alvaro Santos, Chantal Thomas and David Trubek, eds. \\ Anthem Press, forthcoming 2019
}

\begin{abstract}
World trade and investment law is in crisis: new and progressive ideas are needed. Rules that facilitated globalization and supported global economic growth are being challenged. A system of global governance that once seemed secure is now at risk as the US ignores the rules while developing countries struggle to escape restrictions. Some want to tear global institutions and agreements down while others try desperately to maintain the status quo. Rejecting both options, we convened a group of trade and investment law experts from 10 countries South and North who have proposed ideas for a new world trade and investment law that would maintain global growth while distributing costs and benefits more fairly. This essay frames the issues and introduces the volume. We look at the impact of trade and investment law on the global distribution of resources, and pay special attention to those who have suffered from trade dislocation and to restrictions that have hampered innovative growth strategies in developing countries. This perspective shapes a progressive trade and investment law agenda that is outlined in the book and summarized here. We suggest new ways to link trade with protection for labor; measures to ensure that gains from trade are used to offset loses; new rules that can protect foreign investments without hamstringing developing governments or harming local communities; innovative procedures to allow developing countries freedom to try innovative growth strategies; and methods to cope with new products like cannabis.
\end{abstract}

We are witnessing a major crisis in world trade and investment relations. The system that operated for decades and facilitated global integration is under attack from many sides. While economic globalization has helped billions emerge from poverty and facilitated the growing geopolitical importance of emerging economies, it has come at a cost. In both rich and poor countries, many have felt the brunt of globalization in the form of job loss, stagnant wages, displacement, economic insecurity and a closing down of opportunities open to the previous generation. Those who have lost are often left without recourse while being admonished on the wonders of the global market. A simmering discontent has finally given way to a backlash against globalization, which has revealed serious flaws in the international economic regime. 
Two voices dominate the public debate right now. On the one hand, there are the nationalists who blame trade for job loss and community decline, propose protectionism and global disintegration as the solution and are willing to walk away from the rule-based system that was consolidated with the founding of the World Trade Organization (WTO). On the other hand are those who defend the current global trade institutions and rules, blaming domestic policy for any maldistribution, and are bent on preserving the status quo.

Our view is that this binary is too limited. We recognize that the existing framework has generated some benefits in the North and the South, but also point out that it has created winners without compensating losers. We can see that there are benefits to multilateralism and a rulebased institutional framework while highlighting that the current system imposes constraints on domestic policy choices that restrict strategic choices and limit economic growth. And we can indicate that it provides windfalls and rents for corporate interests, exacerbates inequality within and between nations, contributes to societal fragmentation and feeds reactionary politics-all without concluding that either nationalism and protectionism or total global deregulation provide the only correctives.

Our quest, then, is for a different type of global economic regime, one that recognizes and confronts the many pitfalls that have fueled the current backlash. World Trade and Investment Law Reimagined: A Progressive Agenda for an Inclusive Globalization seeks to move beyond the dominant debate by proposing ideas, policies and institutional reforms for a progressive reshaping of globalization.

Our approach assumes that globalization has been driven by legal changes in the late 1980s and 1990s that were inspired by a particular vision of world order and development. It has many dimensions, but two central pillars are the global trade regime that was formed by the WTO and numerous preferential trade agreements, and the less centralized investment regime structured by bilateral investment treaties (BITs) and designed primarily to protect foreign investors in developing-country markets. 
We look in this volume at these and related systems, building on decades of analysis and critique to explore new directions. We assembled 21 experts from 10 countries to write short essays analyzing specific problems of the current system and proposing solutions. We met and discussed these essays under the rubric "Rethinking Trade and Investment Law." 1 As part of these discussions, we also convened an exchange on Dani Rodrik's book Straight Talk on Trade, one of the earliest, and most fully fledged and nuanced, critiques of globalization in the so-called post-Brexit period. The exchange around Straight Talk on Trade also provided a fulcrum for bringing together heterodox perspectives from economics and from law. As we hope to show here, this kind of exchange between disciplines can sharpen the contributions of each, and perhaps even push our collective analysis further than it might otherwise go.

In this introduction, we identify the main ideas in the book. The next section, "Cross-Cutting Themes," sets out major themes that cut across the substantive topics and individual essays. "Rethinking the Political Economy of Trade" reconsiders the political economy of global trade through an assessment of Straight Talk on Trade. "Setting the Stage for a Progressive Vision" reviews important issues in world trade and investment law today. And "Toward a Progressive Agenda” lists some concrete measures for inclusion in the progressive agenda.

\section{Cross-Cutting Themes}

The book deals with a wide range of issues, from the rise of China to measures to improve local community participation in decisions over foreign investment. But four overarching themes can be seen throughout the volume: distribution, policy flexibility, the changing role of the state and the role of law and legal institutions.

\section{The question of distribution}

An overarching theme is economic distribution and international economic law (IEL): how economic gains and losses are shaped by international institutions. The globalization backlash has been fueled by a sense of disappointment and frustration with the economic results. Job

\footnotetext{
${ }^{1}$ Hosted by the Institute for Global Law and Policy, Harvard Law School, April 2018.
} 
losses and displacement are in fact predicted by trade theory as a consequence of liberalization, but governments have not done much either to compensate those who have lost or to find ways to share the gains more widely. In fact, in some countries, globalization has coincided with the hollowing out of social protection mechanisms designed to compensate losers and provide insurance in hard times.

Two major distributional issues emerge from the discussion: the distribution of resources between labor and capital and the effect of globalization on income distribution between and within nations. Trade and investment law agreements create benefits for capital by protecting property, placing limits on regulation and expanding the available pool of labor. At the same time, critics argue, the regime has done little to protect labor or enhance its condition globally. And, if we look at this from the perspective of income distribution, we see negative effects of globalization in the period from the late 1980s onward, but also some positive ones that need to be preserved. The book addresses both issues.

Branco Milanovic offers a useful diagnosis of the income distribution effects of globalization. ${ }^{2}$ Three conclusions stand out. First, income inequality between countries, when accounting for population size, has been reduced, thanks in large part to the spectacular income growth of China and India. However, the difference in average incomes among countries, if population size is not factored in, has increased. This experience makes clear that one of the strategies to reduce inequality among countries is to promote conditions for rapid economic growth in developing countries. That requires a global trade and investment system that can encourage—or at the very least accommodate-pro-growth strategies like the ones followed by successful countries, which often diverged from the reigning model. This lesson should bring into focus the laws and institutions, both at the international and domestic level, that made this growth possible.

Second, if we consider global income, the winners of globalization were the very rich everywhere, the middle classes of some emerging countries and much of the bottom third in global income distribution. It is because globalization has been beneficial for many in the

\footnotetext{
${ }^{2}$ See Branco Milanovic, “Global Income Inequality in Numbers: In History and Now,” Global Policy 4, issue 2 (May 2013), and Branco Milanovic, Global Inequality: A New Approach for the Age of Globalization (Cambridge, MA: Harvard University Press, 2016).
} 
developing world that we seek to reimagine, not reverse it. The big losers were the bottom 5 percent - including the populations of many least-developed countries in Asia and Africa — and those at the 75th to 90th percentile of global income distribution: neither saw any increase in income. The group in the 75th to 90th percentile globally mainly consists of the middle class in rich industrial democracies whose incomes stagnated while the rich in these countries moved ahead: these relative losses are a major source of the ongoing globalization backlash. Politicians in Europe and the United States have responded to the grievances—real and imagined—of this demographic to ascend to power while challenging the international regime that produced this result. A crucial part of a powerful response to these ills, largely overlooked in these same industrialized countries, is the compensatory and social insurance mechanisms that would allow people to confront the adversities of globalization, and we address this need in the volume.

The most striking feature of global income distribution, however, is the importance of location as a prediction of individuals' income in their lifetime. Country of origin largely continues to determine a person’s economic prospects in life: “[M]ore than 50 per cent of one’s income depends on the average income of the country where a person lives or was born (the two things being the same for 97 per cent of world population)." ${ }^{3}$ Compared to the nineteenth century, Milanovic argues, we have moved from a class-based world to a location-based world. In the nineteenth century, national average incomes among countries varied less than did incomes within countries, which differed greatly. Workers' experience, income and life conditions were similar in much of the world. Solidarity among workers everywhere made sense, and it could inspire revolutionary movements. Not so today, Milanovic argues, since the poor in a rich country like the United States would still be high up in the global income distribution scale. A sense of shared experience among workers — or the poor—in rich and poor countries is hard to come by. "Around 1870, class explained more than two-thirds of global inequality. And now? The proportions have exactly flipped: more than two-thirds of total inequality is due to location." ${ }^{4}$ Given large differentials in national incomes, and given how much distribution of global income depends on location, powerful incentives for people to move will continue to exist. That is why Milanovic proposes that, in addition to promoting higher rates of growth in

\footnotetext{
${ }^{3}$ Milanovic, “Global Income Inequality in Numbers: In History and Now,” 204.

${ }^{4}$ Ibid.
} 
poor countries, we should consider freer migration from poorer to richer countries as one way to reduce income equality.

The recognition of the distributional impact of trade and investment agreements has created a new narrative that we engage with. Critiques of economic insecurity and precarious jobs in the developing world associated with globalization have long been familiar. What seems new in the current moment is that these critiques, and the opposition to the international economic regime, are now also coming from rich countries. More strikingly, those critiquing globalization are now in power in the United States and the United Kingdom and are on the rise in Europe. This may provide an opening to reform a system that had looked very resilient to change. The direction and potential effects of the change, however, remain unclear. In this volume we seek ways to ensure that any changes will ensure that trade and investment law promotes growth and global equality and helps the have-nots in the world. That is the progressive agenda!

The maldistribution effects of the trade and investment regime mark the starting point for many of the essays in this volume. The authors overwhelmingly reject the mainstream economics argument that the international economic regime serves only to enhance overall efficiency or increase aggregate welfare, just as they question the mainstream notion that concern with societal distribution should remain exclusively a national question. In any given setting, there are many possible efficient outcomes, and legal rules set at the international level directly affect how the gains are distributed. The global legal architecture shapes the global market, creating different entitlements for governments, firms, workers and consumers, defining how they can operate and decidedly affecting the distribution of power and wealth.

If the current distributional landscape is socially unacceptable, then the global agreements and institutions that underpin it can and should be reformed. None of this precludes national obligations to establish policies for compensating losers from global economic reallocation or creating economic opportunities for those who have fallen behind. In the end, however, the goal is to make globalization work for those who have been hardest hit or have remained excluded, not to revert to a narrow self-regarding economic nationalism. To that end, we have suggested ways to strengthen labor versus capital, improve income distribution globally by reducing 
obstacles to policies for growth with equity in the developing world, capture some of the gains from trade for those who may be negatively available by it and allow people affected by trade some access to higher-income locations through controlled trade-migration linkages.

\section{Policy flexibility versus locking in the social agenda in trade agreements}

Some essays advocate for policy flexibility and autonomy, while others propose new rules and restrictions on labor and social policy. For some authors, the main problem of liberal globalization is that it is too restrictive on countries' economic policies. Authors like Dennis Davis and Fabio Morosini on investment and Kevin P. Gallagher on cross-border financial flows conclude that the regime has impinged on states' rights to regulate and that states need to reclaim their space by either exiting from or reforming the system. Other authors, such as Frank Garcia and Thomas Streinz, would like trade agreements to tax economic transactions for purposes of social compensation. They point out that states have failed to compensate losers domestically, either because they are unwilling or because of competitive pressures. Locking in tax and compensation at the treaty level would make the project of redistribution more effective by helping to ensure that states can make good on such promises.

This tension is probably best captured in Gregory Shaffer's essay, where he proposes a bargain: developing countries get policy space for pursuing industrial policies, such as exceptions to the subsidies rules, while rich countries get a new mechanism for countering social dumping. One may think about this as a rebalancing that loosens restrictions in one domain and tightens up the space in another. Shaffer is explicitly trying to operationalize some of Dani Rodrik's proposals. In response to the potential objection that social dumping remedies would harm developing countries’ competitive advantage, Rodrik has argued that the best strategy for developing countries would be to expand their policy space and experiment with pro-growth programs. In the end, nothing would improve labor conditions more than domestic economic growth.

At one level these proposals seem to be in conflict, with one group of authors arguing for fewer international restrictions and another for more. To be sure, these ideas are in tension but do not necessarily represent a fundamental contradiction. The authors as a whole continue to believe in 
the importance of regulation at the global level; they just disagree with the current balance between global restraint and national autonomy. They believe that rebalancing globalization requires a more nuanced and pragmatic approach that expands flexibility in some domains but shrinks it in others, depending on the desired consequences.

\section{Rethinking the role of the nation-state: Neoliberalism, value chains and all that}

A question running throughout this book is what role the nation-state should play in this new era. Many of the authors argue that we need to rethink the role of the state. This is a major issue in Straight Talk on Trade. Rodrik believes that global governance has weakened the nation-state's capacity to manage the economy and provide social protection. The essays commenting on Rodrik in "Rethinking the Political Economy of Trade" and others in the volume echo this concern. They note that under the pressures of neoliberal doctrines that promoted the idea of a single global market and a limited role for the state, a whole system of BITs and free trade agreements (FTAs) has been created that curtail national policy space, thus facilitating unrestricted globalization. This has generated resistance among those negatively affected by global trade and investment and fueled the current backlash. Several essays document these effects and call for measures to increase the power of nation-states in economic and social policy.

In drawing attention to the law-created nature of the current globalization and urging a stronger role of the national state, many authors clash with some of the prevailing wisdom about the world economy. Take, for example, the well-known work of Richard Baldwin, whose challenge to the role of the nation-state is raised in the exchange between Rodrik and Thomas in this volume. Baldwin argues that the world is changing ever so fast and, driven by technological innovation and changes in the modes of production, countries are converging in the same model of globalization. ${ }^{5}$ We are, according to Baldwin, in a new globalization, marked by lower costs of trade and of information and communication technology. Baldwin argues that "the new globalization should change how governments think about their policies." ${ }^{\prime 6}$ Comparative

\footnotetext{
${ }^{5}$ See Richard Baldwin, The Great Convergence: Information Technology and the New Globalization (Cambridge, MA: Harvard University Press, 2016).

${ }^{6}$ Ibid., 13
} 
advantage has been denationalized, he claims. Accordingly, developing countries are not building the entire supply chain domestically but instead joining international supply chains to industrialize. In this view, nations are no longer, or will not be for long, the relevant unit of policy analysis. Rather, firms are crucial entities. Economic changes are increasingly unpredictable. Winners can't be grouped only by sectors and skills. There are winners and losers even within the same sectors and skills groups, depending on production stages and occupations. One corollary of Baldwin's views is that it would be practically impossible for nations to pursue an industrial policy to create comparative advantages in specific national sectors.

While our authors accept Baldwin's description of the importance of global value chains (GVCs) and their effects on development strategy, they take a very different approach to how we got here and where we should go. First, Baldwin's account places economic change, and particularly technological innovation, in the driver's seat, while in this book we stress the role of law in motivating or enabling those changes. We show that the lower transportation costs and more rapid movement of ideas that Baldwin notes were the result of new rules and institutions. It is not a coincidence that his "second unbundling," whose origin he locates in the 1990s, happened during a time of a momentous change in the rules of the international economic order, associated with the rise of the Washington Consensus. Baldwin seems oblivious to both the social and political forces that made this globalization possible and the importance of the rule changes that established it.

Not only does the conventional wisdom overlook the extent to which this new global economy is constituted through law, but it also fails to recognize the way this new market has become “disembedded" and does not autonomously take into account social and political concerns. Neoliberal governance has helped create markets that are distant from society's norms and values. Our authors propose policies to re-embed the liberal market with societal commitments regarding the distribution of opportunity and wealth. But to do that, they recognize, we must restore some of the nation-state's capacity lost through globalization.

The nation-state, our authors argue, must continue to play a leading role in creating the kinds of institutions needed for an international market that both facilitates trade and investment and 
preserves social integration. Of course, if states have more policy space, they must calibrate their policies to the changing features of the global market. In addition, while both the argument for increased policy space, in the section above, and the argument on behalf of the nation-state here support national institutions insofar as they can be used to address local social imperatives, it is important to note that this does not happen automatically. States can, of course, be subject to corruption and capture in both the Global North and Global South. The phenomenon of the socalled strong states that appeal to nationalistic considerations, while in fact marginalizing and subordinating the less advantaged within their societies, is well understood. Indeed, this is one reason the authors' interventions as a whole refrain from any call to populism or nationalism. They recognize that decisions of national governments are not sacrosanct and can be limited by global provisions. But states remain key players and can reshape the existing international order in ways that will both facilitate growth and ensure that globalization is fairer and more politically acceptable.

\section{Background conditions: Focus on the right law}

An important critical insight, going back all the way to legal realism, is that the most relevant legal regimes for questions of distribution may not be the most apparent. Often, it is the background norms of property, contracts or torts - those we take for granted as constituting the market—and not those foreground norms specifically intervening in the market or regulating it (such as labor, the environment or health) where the most promising interventions may lie. This insight helps identify the interaction of different normative orders and see how they may influence one another. Given the concern with jobs and labor conditions, much of which has fueled the globalization backlash, one may think that labor chapters in trade agreements are vital and need to be perfected and better enforced. But Kerry Rittich and Alvaro Santos both conclude that if one is concerned about labor conditions, such labor chapters are not where the real action may lie.

They each contend that labor chapters could disappear from trade agreements and little would happen. Rittich notes the importance of background laws and institutions that structure the workplace and help determine the consequences of trade liberalization. The most powerful 
responses to redressing the effects of trade on labor, then, may lie in identifying what changes to background laws might improve the resilience of the social benefits of work. One answer lies in delinking health insurance and other Social Security provisions from work, making them universal. This would reduce incentives to cut labor costs or hire informally and would give workers flexibility without insecurity. Another answer lies in linking firms' responsibility for labor conditions in their contractors' and subcontractors' facilities along the global supply chain. Santos also suggests looking beyond trade agreements to areas like government procurement, investment and social dumping remedies and supports including more robust pressure for labor law reform in trade agreements, citing the recent agreement between the United States, Canada and Mexico.

Dan Danielsen and Robert Wai echo the concern for a broader understanding of the legal orders that affect transnational flows of goods and people. Danielsen notes that trade and investment law as we know it has little purchase on the legal institutions that shape global value chains and affect the distribution of rents from these chains. Wai tells us we need to think of normal trade law as incorporating a wide range of legal orders, not just those thought of as IEL.

\section{Rethinking the Political Economy of Trade}

Globalization has been driven—or at least supported—by a political economy vision that advocated for open markets, private enterprise and limited state intervention while assuming that the resulting policies driven by this vision would benefit all and be compatible with democracy. To develop new approaches to trade and investment law, we need to challenge this vision and work toward a new one. Few sources are more valuable for such an endeavor than Straight Talk on Trade. This volume, which synthesizes Rodrik's work, outlines the type of political economy approach that must undergird a progressive agenda. What follows is the result of an exchange between Rodrik and four of our contributors from whom we solicited comments on the book's relevance for the field of IEL and policy. ${ }^{7}$ We summarize their interventions and Rodrik’s response in the following section.

\footnotetext{
${ }^{7}$ The initial dialogue occurred at the workshop on Rethinking Trade and Investment Law, referenced above (see $\mathrm{n}$. 1).
} 
The commentators identified several key ideas set out by Rodrik that deserve consideration as we craft a new approach to IEL.

\section{You can have too much globalization: Excessive globalization has undermined democracy}

“Elites,” notes Thomas, "have pushed economic integration far past the point where political institutions have been able to keep up. The imbalance must be corrected in one of two directions: 'expand governance beyond the nation-state or restrict the reach of markets.' The tendency of 'polite company' among cosmopolitan elites is to speak only of the former, but Rodrik makes a strong argument that the second option should be considered, consciously going against the conventional tendencies of his cohort of international economists.” Shaffer notes that Rodrik believes "we need to place the requirements of liberal democracy ahead of those of international trade and investment.” If, despite the gains from trade, economic globalization puts liberal democracy at risk, Shaffer adds, then we need to readjust the balance in favor of more domestic policy space and less economic integration facilitated by IEL. Santos takes up the same theme but more cautiously. Looking at Rodrik's principles for fair trade, which would allow a nation to ban imports that affected core social values, Santos notes that such rules are useful, but they could, at the same time, affect core social values in the exporting nation. Santos argues that the tension between two countries' standards needs to be addressed deliberately, preferably by a global institution, considering the economic and social consequences of the available options.

\section{Loosen the ties that bind: Trade and investment law has constrained policy experimentation}

Rodrik parts company with many economists and development agencies that mention a single formula for growth. He notes that economic policy must be based on local conditions and the only way to find the optimal growth path is through experimentation. He sees current trade and investment law as insensitive to context and restrictive of experimentation. Shaffer notes that Rodrik "believes that countries must experiment to find the optimal development path"; Shaffer argues that IEL should facilitate such experimentation. 


\section{Regulation starts at home: The nation-state remains the key institution for regulating the economy}

Noting that "markets require rules to facilitate economic exchange, create stability and provide a sense of legitimacy,” Shaffer quotes Rodrik's argument that the nation-state is "the only game in town when it comes to providing the regulatory and legitimizing arrangements on which markets rely.” Economically, Shaffer concludes, “the state enables the mobility of resources, enhancing efficiency and increasing productivity essential for economic growth and social welfare. Politically, the state fosters the spread of participatory, representative institutions, giving rise to liberal democracy. Legally, the state creates public order through laws and institutions that reduce violence and uphold the social contract.” Santos agrees that the state remains a central institution but notes that nations can be the source of inequality and oppression. He suggests that Rodrik's enthusiastic embrace of the nation may entail risks and that other dimensions of governance must play a role. Echoing Santos’s concerns about relying too much on the nationstate, Thomas asks whether if the growth of GVCs and the resulting deterritorialization of production may require more, not less, regulation beyond the national level.

\section{No more tigers? The threat of premature deindustrialization}

Rodrik fears that changes in the world economy may make it hard for developing nations to follow the path of the Asian Tigers and China. These regions relied on growth for exports of manufactured goods to advanced markets. Rodrik worries that the opportunities for such strategies have declined due to technological advances and China's first-mover advantage in many industries. Thomas summarizes this argument:

The obstacles to growth through conventional industrialization lie both in contemporary technology and in contemporary trade. With respect to technology, because manufacturing is now much more knowledge- and capital-intensive, barriers to entry are higher and less available to countries further down the economic ladder. With respect to trade, not only does the sheer formidability and market dominance of current competitors like China reduce the possibilities for market share gains for smaller economies, but also international 
trade rules have now reduced the amount of protection countries can introduce to attenuate that market dominance by locking in commitments to market openness.

While acknowledging the importance of Rodrik's concerns, Thomas notes that trade law is not as restrictive as Rodrik suggests. And she thinks that the clustering effect might help some developing regions overcome premature deindustrialization. She wonders "whether it really is the end of industrialization or whether alternatively a place remains for localized industrial production among today's low-income countries if they can amend and manage trade rules to be supportive and can operate with reasonable governance, effective institutions and sound 'targeting' of promising industries and firms.”

\section{It's the economists, stupid: We need a new approach to trade in economics and other social sciences}

The commentators welcome Rodrik's critique of trade economics and its use in policy debates. Rodrik has questioned the standard models, and Gallagher echoes that critique, though he also argues for a systemic view of these academic failures, seeing them not only as the fault of trade economists but as pervasive in the social sciences more generally. Gallagher notes that standard models fail to take into account the effects of trade agreements and make unrealistic assumptions. He states that "[t]he modeling exercises that dominate trade policymaking take the form of computable general equilibrium (CGR) models that 'work' only if good trade is modeled and if there is perfect competition, fixed employment, no externalities, no international investment and no technological change.” Gallagher also points out that models do not take distribution into account and fail to measure the impact on losers:

While the gains from trade are small relative to entire economies, they are highly concentrated into the hands of a few in a small number of key sectors (pharma, finance and factory food). The losers from trade are also small relative to entire economies but highly concentrated in a few sectors (manufacturing, of course). In addition, the losses may be small relative to economies but overwhelming relative to the budget constraints of the losers themselves and the alternative opportunities they may have. 
As Santos points out, Rodrik recognizes indeterminacy in the models, stating that "[e]conomics is really a toolkit with multiple models_each a different, stylized representation of some aspect of reality.” There are competing models that lead to different explanations and policy recommendations. Rodrik celebrates this pluralism. The key, and this is what Rodrik is after, is to learn how to choose between competing models.

While Rodrik believes this to be possible apparently without injecting normative preferences, Santos is "more skeptical of the project of developing a method to choose the 'right' model." Santos refers to Rodrik's own “war of trade models” blog post concerning the effects of the Trans-Pacific Partnership (TPP) where Rodrik argues that “neither side’s models generate numbers reliable enough on which a case for or against the TPP could be made. Just about the only thing we can say with some certainty is that there would have been gainers and losers.” Santos is not convinced that there is a meta model that can be employed to select the right model to adjudicate important policy debates.

Gallagher summarizes what he takes from the book: “[T]he winners of globalization are writing the rules of globalization, economists are cheerleading, other social scientists are out to lunch, and the working class in the North and future entrepreneurs of the South have had enough.”

\section{Rodrik's rejoinder}

Acknowledging the comments, Rodrik welcomed the observations regarding the limitations of standard modeling as complementary to the overall viewpoint put forward in Straight Talk on Trade. Rodrik accepted Gallagher's corrective critique of the social sciences more broadly. He replied to Santos's suggestions that there is no value-free meta stance from which models can be chosen by noting that, while this is true, the methodological focus on data gathering does force a certain "discipline in the process” that is nonideological. "Objective facts do exist," Rodrik writes, “and they do matter.” And he welcomed Shaffer’s reference to the employment of insights from legal realism refining economists’ analyses of law. 
With respect to specific types of policy reform, Rodrik also agreed that there are limits to the capacities of the nation to manage global trade but felt that any move to the global level for governance and efforts at international harmonization tend to empower business interests to the detriment of other concerns. And he met Thomas's queries regarding challenges to national governance from the contemporary economic landscape, such as whether the importance of GVCs might require regulation to move to regional or global levels, by observing that the GVCs are far less important than generally thought.

\section{Setting the Stage for a Progressive Vision}

The terrain in IEL is shifting. New geopolitical alliances are forming, resistance to some aspects of the regime have emerged, economic structures are changing, and the costs of globalization have become more apparent and more troubling. In this part, we summarize how the authors in the book view these and other developments, which form the context in which we must develop a progressive vision.

\section{Mapping the new context for trade and investment law}

The trade and investment law regimes took their current shape in the 1990s. Almost three decades later, there have been major changes that must be taken into account in the progressive agenda. These include the rise of China, the proliferation of preferential FTAs, the persistence of heterodox models and the resistance of emerging economies to some of the constraints of the regime. Poul Kjaer paints these developments in stark terms: he sees them as the result of the decline of the West and the world order created after World War II:

The breakdown of the Eurocentric world is now being followed by the breakdown of the Western-centric world. The Eurocentric world started to collapse in the late nineteenth century with the rise of the United States, and later Japan and the Soviet Union, and became manifested in the mid-twentieth-century decolonization processes. Today the concept of the West is disintegrating, with Europe and the United States moving steadily apart in political, economic, social and cultural terms and becoming strangers. 
Furthermore, this development unfolds with the rise of non-Western powers, most notably China, greatly exacerbating the consequences.

The emergence of this new context presents both challenges and opportunities for a progressive agenda.

Cometh the dragon: The rise of China

China's rise to economic predominance, and the West's reaction to it, arguably constitutes the most important development affecting trade and investment law today. China has benefited greatly from globalization. Moreover, although current trade and investment law tilts heavily toward convergence on market models of political economy, thus creating pressures on China's heterodox economic organization and strategy, China has resisted much of this pressure and has recently doubled down on its commitment to state capitalism. While these deviations from the liberal market model were tolerated when China was weak, its industries posed no threat to those in advanced economies, and there were hopes for gradual convergence, everything has changed now that China is the second largest economy in the world. Chinese companies are already globally competitive, and China aspires toward even greater leadership in many key industries. The flood of exports from China and China-centered value chains that drove China's remarkable rise have caused serious dislocation in industries and regions in both advanced and developing economies.

Faced with this challenge to their economic predominance, countries North and South are scrambling to figure out how to deal with China. In the North, leaders are asking whether they should double down on pressures on China to liberalize or look for new forms of accommodation with an economy that is now closely linked to their own and slated to become the world's largest in the not-too-distant future. Should they pressure China to reform its labor market or seek to delink their economies from China through tariffs and other barriers? In the South, countries are both attracted by Chinese investment and trade opportunities and concerned about Chinese dominance. China has embarked on a major global initiative both through investments everywhere and through the massive Belt and Road Initiative, which offers infrastructure 
assistance to countries in many parts of the world. China is seeking closer integration in Asia through the Regional Comprehensive Economic Partnership (RCEP). Countries North and South are trying to take advantage of these developments, and these new relationships reverberate through the whole field of trade and investment law, generating many of the issues taken up in the book.

Coping with the continued diversity of economic models

When the current regime took form, many thought that the world would gradually converge on a model of regulated market capitalism. Andrew Lang notes,

[T] he years following the collapse of communism seemed to herald a radical reduction in the global economy's degree of institutional diversity as states throughout the former “second” and "third” worlds converged toward a single model of market capitalism. But the reality has proved more complicated: the national marketization projects initiated during this period have each evolved according to different dynamics, resulting in the emergence of a variety of new and heterodox market forms in different countries and regions of the world.

This new pluralism and heterodoxy have presented a major challenge to the regime and led to resistance by emerging economies that have challenged existing rules and blocked new ones. Sonia E. Rolland and David Trubek describe this tension and note that until recently it seemed to lead to a fragile equilibrium in which developed countries tolerated some diversity while emerging economies accepted some restrictions to gain access to developed country markets. They observe that

... despite tensions between the current international economic law (IEL) system and the policy preferences of many emerging economies, countries of the Global South have managed to achieve some kind of balance between the neoliberal thrust of the system and their desire to pursue strategies that—from a neoliberal viewpoint—are heterodox. The result is a system they can use to further their own ends and one that only intrudes on their 
policy space to a tolerable degree. Think of it as a "truce" between a radical liberalization campaign and strong resistance in the name of state-led growth and sovereignty.

The authors think the truce has offered benefits to both developed and developing countries. They do not consider it an ideal situation for developing countries but rather the best they could get in the context of the time. However, they fear that even these partial victories may be at risk due to recent actions, especially those initiated by the Trump administration, which may be destabilizing the truce. This fear is echoed by Lang, who notes that from the beginning of the General Agreement on Tariffs and Trade (GATT), the regime has dealt with institutional diversity and heterodox policies in two ways: sometimes serving as an interface to mediate tensions between competing economic systems and sometimes as a force for convergence along free market lines. During much of the post-World War II period these two tendencies remained in tension, and an unsteady compromise between them prevailed. However, Lang notes, during the last decades of the twentieth century, in part as a result of the disruptions to existing patterns of comparative advantage caused by the rise of new capitalist forms in East Asia, the balance shifted toward convergence, and this trend has continued to this day. "It is now perfectly apparent," he states, "that a large part of the new agenda of rulemaking in international trade agreements is designed specifically to place additional constraints on new institutional forms emerging in China and elsewhere. The development of new rules on state-owned and statecontrolled enterprises, alongside the concerted use of existing subsidies rules to challenge the practices of Chinese state-owned enterprises, is the best example.”

Echoing a Rodrikian theme, Lang points out that institutional diversity can be a positive force in the world economy as it encourages the kind of experimentation that can lead to faster and more sustainable growth. For that reason, he urges us to think beyond the compromise,

imagining the present system not just as a mechanism for managing the interface among different economic systems or as a force for reducing institutional frictions, encouraging institutional convergence and leveling the international competitive playing field, but also as a system for encouraging democratically driven institutional experimentation. 
Many of the essays, such as those of Poul Kjaer and Robert Wai, share Lang's sympathy for the idea of trade law as an interface between countries’ different institutional preferences and values, rather than a tool to create global homogeneity. In addition, Straight Talk on Trade offers a great example of this position as Rodrik argues that we should allow regulatory diversity up to a point and unlock the straitjacket—real and imagined — of globalization in favor of greater policy autonomy. In this concept, trade law would serve as a neutral link between disparate economic systems and provide results that would allow maximum feasible diversity while facilitating trade relations.

Although showing support for a system that avoids imposing one country's economic system on another, several authors question whether such an interface can really be neutral and doubt that the system in action could really weigh each country's interests equally when there is conflict. The asymmetry of power plays an important role in trade law outcomes and often is reflected in notions of what the normal baseline ought to be; for example, what counts as a distortion in the normal market or protectionism. Similarly, the interface position relies heavily on the nationstate as the agent that could effect change and improve the conditions of work and of life that have led to the globalization backlash. While the authors believe that nations should be given more leeway to experiment with different development strategies, they also recognize that states may not take into account the needs of all within their territory and believe that even an interface system must have some global level standards to protect domestic interests that may not be taken into account in national policymaking. This concern is seen in calls for ensuring that workers in emerging economies are not exploited in the race for growth and that local communities are not ignored or overlooked by the promise of greater national welfare: dealing with these issues may require international-level governance.

Nonetheless, the authors tend to favor an approach that exhibits maximum feasible tolerance for policy divergence in areas like economic organization and strategy, including state-owned enterprises (SOEs) and industrial policy, while calling for more robust global standards in areas like labor markets. This approach would apply to China as well as other emerging economies and is at odds with current US trade policy, which is designed to force China to modify its state capitalist model in favor of a normal market orientation—or punish it if it does not. 
Learning from the fragmentation of world trade law

In addition to the need to recognize a variety of economic strategies and models, the progressive agenda must take into account the growth of preferential trade agreements, each with its own set of rules, and the resulting fragmentation of IEL. There are many such agreements, including agreements that have recently entered into force or are pending as of this writing, such as the Comprehensive and Progressive Agreement for Trans-Pacific Partnership (CPTPP), the EUCanada Comprehensive Economic and Trade Agreement (CETA) and the United StatesMexico-Canada Agreement (USMCA). They introduce new rules, many of which may differ from the global rules established by the WTO. The result is a different trade law for different parts of the world—some call it a "spaghetti bowl” of rules.

To test the range and scope of such agreements and their relevance for the progressive agenda, we looked at the RCEP. Pasha Hsieh describes the RCEP,

The [RCEP] represents a new era of regionalism and offers a distinct paradigm for world trade law. When it is launched, the RCEP will be the world's largest free trade agreement (FTA) and a clear alternative to the extant neoliberal trade regime. Built upon the Association of Southeast Asian Nations (ASEAN) free trade areas, the 16-party RCEP covers half of the global population and 30 percent of global gross domestic product (GDP). It also encompasses the world's most vigorous economies, such as China, India and Indonesia. [...] It also exhibits the Global South’s contemporary normative vision, which challenges the dominant neoliberal approach and the Indo-Pacific strategy of the Trump administration.

Hsieh lists several features of the RCEP that distinguish it from the CPTPP and other Westernled preferential FTAs. These are features that should be taken account of in crafting the progressive agenda. Whereas recent agreements like the CPTPP include provisions that force SOEs to act like commercial actors, the RCEP will have no restrictions on SOEs. In addition, rather than asking all members to enter into a single undertaking, the RCEP follows an 
evolutionary approach that recognizes different levels of development among members, which range from Australia to Myanmar. Finally, unlike most FTAs, the RCEP does provide for some labor mobility, although, unlike the EU’s free movement provision, it is limited to skilled professionals. While in some regards, the RCEP (which is still being negotiated) represents an alternative to current FTAs, which are more restrictive of policy space, in others, like intellectual property, it may turn out to be less innovative.

Kjaer sees regional trade agreements like the RCEP as a harbinger of a more general fragmentation of IEL:

The paradox of globalization is that it is producing global disintegration and increased diversity rather than increased integration and uniformity. The world is likely to be made up by a number of centers with overlapping political, economic, social and cultural regimes, with none of them acting as a singular global anchor.

He sees this as creating both an opportunity and a duty for progressives, urging a rethinking of IEL as an "exercise of reconnection, developing models that match the cultural universes, economic structures and political worldviews of the world’s different regions.”

Expanding the notion of normal trade law

In his essay, Wai takes the analysis even further. He favors the interface approach to trade law but argues that this approach requires us to expand our idea of normal trade law to include a wider range of legal orders and approaches. He envisions a multidimensional transnational law that includes public and private law, domestic and international law. He sees such an approach as necessary to dealing with institutional diversity and fragmentation:

Finding the normal role of law in trade may therefore require a broader sense of the legal orders that help structure not just particular legal claims but also the political and economic bargaining of trade relations. 


\section{Dealing with major changes in the world economy}

Whereas the section of the book addressed above focuses on world trade and investment law, the next section of the book deals with adjacent transformations in the world economy that shape world trade and investment law and so must also be taken into account in a new trade and investment law regime. This is not a comprehensive survey of all relevant changes. Rather, we have selected a few recent changes—supply chains, platform firms, and the legalization of formerly illicit products—to show how legal rules shape global markets, allocate rents and affect development possibilities. These chapters underscore the crucial roles of legal institutions of all types, not just trade and investment law. They show that progressives must both understand fast-changing economic structures and processes and craft new forms of intervention to promote values of equality and fairness.

The progressive agenda for world trade and investment law seeks to revise the rules of the game in ways that will foster growth with equity, particularly including social protection for workers, in both the Global North and Global South. Two authors suggest that changes in the operation of capitalism make that task incredibly difficult. Danielsen's analysis of supply chain capitalism and Jason Jackson's study of platform firms show why existing regulatory tools are inadequate and demonstrate the need for new approaches.

Restructuring of capitalism and the limits of regulation: The supply chain revolution

Danielsen, like other authors, stresses the significance of the rise of GVCs for the future of globalization. He sees that this development radically alters the way we have to think about global governance. While some think this development makes national policy almost irrelevant, Danielsen believes the state continues to be a primary agent in creating the norms of the international markets on which firms rely for structuring GVCs. To make these fairer and ensure maximum gains for developing countries, he asserts, these nations must confront the power of buyer firms and the legal institutions that support them. 
Danielsen notes that the power of buyer firms and the competitive pressures on suppliers mean that the buyers secure most of the rents from these industries, while firms in developing countries are squeezed by competitive pressures. Unless they can deal directly with these conditions, developing countries may be limited in their ability to use exports as a tool of sustained growth. While progressive trade lawyers have argued that reforms in the trade regime could empower developing countries to maximize gains from exports, Danielsen argues that such changes will have little or no impact on growth or poverty alleviation in the developing world unless new tools are fashioned to address inequalities of power in the GVC context. Trade law reform may be necessary to improve the situation, but it is far from sufficient. Danielsen calls for better maps to

illuminate new legal tools and policy strategies beyond the traditional tools of trade law and policy for disrupting the current configuration of power and distribution of resources under supply chain capitalism and enabling more equitable patterns of trade and distribution to emerge.

Platform firms: A new global phenomenon

Jackson's analysis of platform firms like Uber and Lyft represents a similar challenge for regulation at all levels. These and similar firms represent a novel organizational form that has been called a "Nikeficated" networked firm. In principle, they serve as intermediaries that match buyers and sellers and thus claim to simply facilitate transactions between willing parties. In this conception, they hope to avoid most costs of conventional Fordist-era firms and not even take on the more limited responsibilities multinational firms assume in their governance of GVCs. Many platform firms exploit the weak condition of labor in both developed and developing markets to squeeze the workforce. Their rise is fueled by new forms of finance that are willing to bet on strategies designed to secure monopoly rents in markets through use of disruptive tools provided by technology and big data. Jackson notes,

This approach is not directed toward supporting steady profit growth and relatively egalitarian distribution between capital and labor, as in the Fordist era (or the European welfare state model), nor does it seek short-term profits, as in the shareholder value model. 
Instead the strategic objective is monopoly control of horizontally related markets through "winner-take-all market strategies.”

Platform firms like Uber are global actors that operate in local markets. Jackson notes that these firms have been skillful in avoiding the kind of regulation at national and local levels that might ensure for labor a fairer share of the gains from their innovations. Like buyer firms in supply chains, the small core platform firms get most of the rents. Jackson concludes that we need more attention to regulation at local, national and global levels if we want to ensure that these innovations contribute to global growth with equity.

Ensuring new products contribute to sustainable growth with equity: The case of cannabis

In addition to learning to deal with new forms of production and new kinds of firms, progressive trade law must learn to cope with shifts resulting from the emergence of new products into the domain of legal trade. We take the partial legalization of cannabis as an example. In their essay, Antonia Eliason and Rob Howse assess the legal and economic implications of the gradual legalization of cannabis, showing how various legal regimes including international trade law affect the development of this industry. Among other things, they discuss how the legal regime might be mobilized to avoid developing an industry dominated by Big Pharma and Big Tobacco and harmful to disadvantaged classes of users.

\section{Framing a more equitable investment law regime}

Globalization is not a natural phenomenon. It was created in part by legal institutions at the global and national levels. Chief among these are BITs. These agreements give foreign investors rights to challenge the actions of host governments in international arbitral tribunals. Many developing countries signed such treaties in the 1990s, while a few were skeptical and never joined the system. Today, some of the original enthusiasts, chafing under restrictions that BITs imposed, are reconsidering these commitments. To get insights for the progressive agenda, we looked at Brazil, which never signed on to the BIT system, and South Africa, which has recently 
reconsidered its commitment to BITs. We also look at how BITs can lead to investments that disproportionally impact local communities and explore ways to minimize such damage.

Enthusiasm, skepticism and withdrawal: South Africa and Brazil

In his study of South Africa's history of engagements and disengagement, Davis notes that behind the movement toward BITs was a vision, articulated by the World Bank during the 1990s, that imagined "a fully integrated global economic order in which investment would be unfettered by national regulation designed to promote indigenous objectives and would inevitably be located where significant returns could be obtained.” By guaranteeing protection for foreign investors against adverse actions by national governments, BITs helped create such an order.

South Africa's embrace of BITs is illustrative of what made developing countries sign on to a system that limited their sovereignty and displaced their judiciary. This decision came after the African National Congress (ANC) came to power. The new government sought to rectify the wrongs created by the apartheid regime while stimulating economic growth. To that end, the government hoped to attract foreign investment. But, Davis notes,

Foreign investors were concerned about the legacy of the history of postcolonial African states, which had embarked on a course of economic nationalization together with a proclamation of redistribution of economic growth. With this history in mind, the British government, under the leadership of then prime minister John Major, who was concerned that the ANC might expropriate British assets in South Africa, was the first to approach the newly installed South African government with a BIT proposal.

The BITs South Africa signed were designed to have a twofold effect. On the one hand, they would deter the country from adopting regulatory policies and nationalization plans that were inconsistent with the interests of foreign investors; on the other, they would guarantee to investors compensation should deterrence fail and investor interests be threatened. 
While South Africa signed numerous BITs, initially little attention was paid to the potential tension between the commitments made to investors and the goal of redressing wrongs created by the apartheid regime. But in 2006, South Africa was faced by a claim that its recently passed mining law amounted to a direct or indirect expropriation in violation of a BIT because it both required mine owners to get a license to continue exercising common-law rights and required that 26 percent of company stock be held by historically disadvantaged South Africans. Although eventually settled, the case drew attention to the conflict between treaty obligations and important social policies. The result was that the country has withdrawn from some existing BITs and passed new legislation providing that future investor-state disputes should be handled by its domestic courts. So far, there does not seem to be a decline in foreign investment resulting from this change.

In his study of Brazil, Morosini also recounts the South African experience, in the course of explaining that Brazil never entered into a standard BIT. Initially, Brazil avoided any kind of investment treaty, but recently it has started signing a very different kind of agreement that stresses dispute prevention, has more limited rights for investors than has been the norm in BITs and does not allow for investor-state arbitration. He notes that, despite its reluctance to agree to BIT-type protections, Brazil has been a major recipient of foreign direct investment. Drawing on these two experiences, Morosini suggests that investment law should include an expanded right to regulate, explicitly allowing states policy space for goals like redistributive justice and industrial policy experimentation.

\section{Protecting local communities impacted by foreign investment}

Nicolás Perrone adds another dimension to the critique of investment law. Noting that the literature on international investment law and policy has consistently avoided the role and interests of local communities, he points out that, especially in natural resource and infrastructure projects, local communities are often the most affected, while national governments, eager to attract foreign investment, may overlook these impacts. The solution, he suggests, is to require local participation at every stage of the investment approval process: 
Local participation should begin as early as possible and continue throughout the project. [...] The scope of participation, on the other hand, should vary depending on the stage of the project. Before establishment, local actors should be protagonists of the human and environmental impact assessment. [...] During and after the investment, local communities should also have an important role in the governance of the project.

Needless to say, ensuring such participation would require a major change in investment law. Perrone notes that it "would imply a shift from a regime based on the rule of law and dispute settlement to a more relational and participatory model.”

While much of the critique of investment agreements has come from developing countries, voices in the North have also been heard. For example, as Santos points out in his essay on labor, labor advocates in the United States have criticized BITs because they may encourage offshoring of jobs: this position has found some favor with the Trump administration.

\section{Supporting development}

Many of the essays in the book deal with conflict between trade and investment law and development strategies in emerging economies. Two of our authors, Kevin Gallagher and Greg Shaffer, home in on specific issues and suggest reforms.

\section{Facilitating heterodox approaches}

A dominant theme in the volume is the need for a more pluralist approach to economic models and development strategies. As discussed above, many of our authors, from Rodrik to Lang to Morosini, contend that standard trade and investment law no longer takes an "interface” approach that tolerates heterogeneity and increasingly pressures states to converge toward a free market system. Intolerant of heterodox strategies, this approach deters the kind of experimentation that they believe is essential for sustainable growth with equity. Shaffer pays special attention to this

problem and suggests specific policies that could reverse the trend toward convergence. In a two- 
pronged essay that deals with industrial policy, social dumping and their interrelation, Shaffer stresses the importance of allowing policy space for experimentation:

Considerable policy experimentation is needed to catalyze economic development since no one knows in advance what works. This is particularly the case given the vastly differing contexts that countries face. Rodrik and others critique WTO rules for taking industrial policy options off the table for developing countries. Industrial policy experimentation for development could be expressly authorized by amending existing WTO agreements, which already provide a framework.

Shaffer outlines reforms of WTO law needed to make this work. They would include general principles, substantive criteria, time limits, and reporting and transparency obligations. Industrial policies that would otherwise be WTO-inconsistent would be allowed if their aim is greater productivity. Only developing countries would be eligible, and exceptions might be time limited or designed to fade away once an industry became globally competitive. As a check on the potential impact of such rules, Shaffer proposes to allow other WTO member states to impose countervailing duties in some cases. He notes,

This proposal would represent a return to the trade policies under the GATT where developing countries could subsidize infant industries, but their products could be countervailed when imported into a developed country where the subsidies caused, or threatened to cause, significant injury to a domestic industry.

While Shaffer's carefully circumscribed reforms would allow some heterodox experiments to proceed, others might call for even more freedom from market-oriented constraints. Whereas Shaffer would allow deviations from the market model on a temporary basis, and even allow countervailing duties during that period, some might argue that countries should be free to maintain alternative models indefinitely without being penalized.

Limiting the effects of capital flows 
Developing countries can benefit from inward flows of investment in stocks and bonds. These funds bolster domestic savings. Gallagher observes,

Cross-border financial investments that are not foreign direct investment—such as bonds, stocks, derivatives and other instruments — can be essential parts of government, banking and corporate finance. Indeed, many developing countries may lack the savings or financial institutions that can help finance business activity. Capital from abroad can fill that gap. Therefore, under normal circumstances, the more capital flowing into a developing country, the more the country benefits.

However, this kind of money is highly volatile and can flow out easily if risks look too great or the gap between the return on such investments and safer opportunities in developed markets narrows. Such counterflows can seriously destabilize an economy. Recognizing that these destabilization effects can undermine development efforts, the International Monetary Fund (IMF) has approved the use of capital controls by developing countries. The problem, Gallagher notes, is that clauses in many trade and investment agreements limit or rule out such controls, thus overriding the IMF:

[T]he trade and investment treaty regime has largely closed the opening in the Articles of Agreement of the International Monetary Fund (IMF) that allow nations to regulate crossborder capital flows. The lack of policy space for regulating cross-border capital flows conflicts with prevailing economic theory and new policy at the IMF that encourages nation-states to regulate cross-border capital flows in certain circumstances.

Gallagher states that many existing trade and investment treaties do have exceptions that would permit capital controls under limited circumstances. But this is not the case with US agreements, which ban controls altogether:

[T]he template for US trade and investment treaties does not leave adequate flexibility for nations to regulate capital flows to prevent and mitigate financial crises. At their core, US treaties see restrictions on the movement of speculative capital as a violation of their terms. 
Moreover, the safeguards in US treaties were not intended to cover the regulation of capital flows.

Because US treaties and others with similar restrictions cover a great deal of the world, this means that the IMF policy has been effectively undermined. Gallagher calls for a reversal of these policies and suggests amendments to treaty language.

\section{Reinforcing social protection: Spreading the benefits of trade, dealing with losses and exploring the trade-immigration nexus}

One of the most important issues the project looked at was the social effects of trade and investment law, and central among these has been the effect on workers. Law has played a major role in constituting globalization, which has led to many changes in the conditions of work worldwide. Jobs have been created and jobs have been lost in both the North and the South. Trade has facilitated the growth of new industries in the South, creating jobs for many, but eliminating others as new imports undermine traditional agriculture and small-scale production. Trade has lowered the cost of many items for consumers in the North and fostered certain high value-added export industries but has also led to the closure of companies unable to compete with low-cost imports. This has led to a loss of jobs and, in some cases, the devastation of cities and regions.

Trade and investment law has done a lot to facilitate the upside of trade but failed to deal with the downside in both the North and the South. The most prominent efforts to deal with costs and distributive impacts of trade in trade and investment law have been the inclusion of labor clauses in trade agreements and the provision of trade adjustment assistance (TAA) for those losing jobs due to trade. The first deals with labor conditions in the South; the second with those who lost jobs in the North. The authors in this volume see both efforts largely as failures. They think that the whole analysis of the social impact of trade has been too narrowly conceived, and they call for a new approach. Rittich concludes, 
At the end of the day, trade liberalization is a social as well as an economic project. The form and substance of trade agreements have profound implications for questions of equality, solidarity, citizenship and justice at the domestic as well as transnational levels. We can continue to focus on labor standards and social clauses hoping they will address, if not entirely fix, the complex distributive problems in which trade regimes as a whole are implicated. But if we move beyond imagining trade regimes simply as devices to set the ground rules of economic competition and begin to view them instead as mechanisms for allocating risks and immunities, powers and disabilities, including among workers and those that employ them, we might well start to make some different choices about their design and content. We will certainly argue more clearly about what trade regimes are for and how they work.

With this in mind, our authors explored five issues:

The limits of labor clauses in trade agreements

“Cross-Cutting Themes” (above) noted that labor clauses in trade agreements may prove less effective than many other background rules affecting the workplace. This critical tack runs against some of the conventional wisdom among progressive scholars, who have advocated in favor of labor clauses even while conceding their flaws. That view reflects a long-standing strategy to improve the conditions of workers in the South and protect labor in the North against social dumping by insisting that trade agreements include requirements for the maintenance of existing labor standards (nonderogation) and recognition of certain basic labor rights. Rittich points out that such labor clauses may be of some use but are woefully inadequate to deal with the impact of trade on labor. Nonderogation clauses and basic rights requirements may have little impact on actual labor conditions on the ground. The existing standards that must be maintained under these clauses may be specific, but they are often very low, while the basic rights that these clauses name, however aspirational they appear, are vague and can easily be interpreted away. Moreover, even if these clauses did have some effect in the designated territory, they may not reach the labor conditions in GVCs. Rittich notes, 
The changing, often-transitory contractual relations that organize the operation of supply chains provide well-documented mechanisms to destandardize the terms under which workers labor. Insulating lead firms from the costs and legal responsibilities associated with employment, they exacerbate distributional inequities.

Rittich concludes, “It is simply magical thinking to imagine that adding labor standards and workers' rights to trade agreements will fix, or even dent, the complex problems at work." She urges a broader approach, one followed by Santos, who argues that if the now revised TPP less the US (now called the CPTPP) and its labor chapter represent the gold standard of globalization as some claimed, then there is good reason to abandon it, just as countries dropped the gold standard in monetary policy in the twentieth century. Pinning our hopes of improving labor conditions on a chapter that relies entirely on adjudication, and whose claims would have to be taken up by states and take years to reach a resolution, is illusory at best. Santos notes that, as pointed out by the US labor movement, reform in other areas of trade agreements may be more promising, including government procurement, investment and social dumping remedies. Santos argues that an overlooked contribution of the TPP was the use of the trade negotiation to put pressure on domestic reform of labor laws and institutions. Consistent with the lessons of the TPP, changes in several of these areas did end up taking place in the new USMCA, beyond the labor chapter. Most important of all was the Labor Annex, whereby Mexico committed to enacting legislation guaranteeing freedom of association and collective bargaining rights.

\section{Prospects for bans on social dumping}

One proposal that would put pressure on developing countries to respect basic labor rights would be to treat low labor standards and weak enforcement as a form of dumping, thus justifying domestic trade remedies. As noted above, Shaffer outlines a proposal to deal with "social dumping of products - that is, products produced under exploitative labor conditions - that sell for less than domestically produced products, thus leading to concerns over wage suppression and reductions of labor protections in the North.” The norms, he suggests, should address only labor rights violations and thus not undercut developing countries' comparative advantage in 
producing goods with lower-skilled labor in the reflection of differences in productivity. Shaffer provides a list of labor norms:

rights against forced labor, child labor, hazardous work and discrimination; establishment of maximum working hours and a minimum wage; and most fundamentally, rights to freedom of association and collective bargaining.

A country deciding to impose duties would need to show sustained violations, and the process should include all the procedural protections available in standard antidumping cases. Rittich agrees that such a remedy might have some use. But she cautions that the standards that are universally acceptable are low and will not help many workers, problems of proof of violation are serious and the rise of such actions could trigger fears of protectionism.

\section{The need to regulate GVCs}

Neither labor clauses nor social dumping actions are likely to reach abuses embedded in GVCsto deal with those, special rules will be needed. Rittich comments,

Because so much production and service delivery is now transnationally organized, finding ways to reallocate costs and risks, benefits and burdens, across GVCs is also a central challenge. Along with more effective taxation of worldwide corporate income, what is needed are legal rules that more effectively bind lead firms to the debts and obligations of their contractors and subcontractors, as well as rules and regimes that permit workers to organize more easily across borders and thereby capture more of the gains of their labor.

Better ways to compensate losers: Overcoming the flaws in trade adjustment assistance

Trade agreements bring about economic adjustment as some industries wax under new conditions and others wane. The goal is to ensure that net gains exceed net losses. The problem is that while the gains come automatically as industries expand under the stimulus of an expanded market, compensating losers requires explicit action by government. While many 
countries have created mechanisms to provide such compensation, they have often proven inadequate. This is especially true in the United States, writes Garcia. The US system, called trade adjustment assistance (TAA), is too narrow in scope. Moreover, funding is both uncertain and inadequate. TAA is often promised as an inducement to get labor support for trade agreements. But dependent as it is on annual congressional appropriations, TAA can be, and usually is, scaled back once agreements have been signed. To avoid this, Garcia proposes that the funding to support those most vulnerable to trade come from trade itself.

Streinz echoes this idea and argues that we need to rethink what trade agreements are all about. He notes that agreements like the TPP create a more open space for private actors to expand their business operations free of restrictions. While multinational corporations (MNCs) are the beneficiaries of the agreements, they are not seen as part of the deal. He notes,

... FTAs are better understood as tools to expand firms’ freedom to operate transnationally. Take the revived Trans-Pacific Partnership agreement, which creates a transoceanic economic megaregion in which tariffs are to be gradually phased out, multicountry production networks benefit from cumulative rules of origin, states' interference with the market is disciplined and domestic rule- and decision-making has to comply with common (global) administrative law standards of transparency, participation, reason giving and review.

Streinz and Garcia agree on the need for mechanisms that would tap the gains from trade and earmark them for TAA and other social programs that would benefit those whose jobs have been lost due to trade. They differ on the best way to do it, with Streinz proposing a passport fee to be levied on all companies that want to enjoy the benefits created by a trade agreement, and Garcia proposing a tax on all financial transactions within the new region. In either case, the revenues raised would go directly into a reformed and expanded TAA, bypassing the process of annual budgets and congressional appropriation. While Rittich does not reject such proposals, she notes the difficulty of separating the effect of trade from all the other drivers of job loss and suggests that more robust measures to protect against job loss of any kind might be more effective. 
Addressing the social cost implications of the trade-immigration nexus in both the North and the South

Well-funded and expanded versions of TAA should help provide compensation for trade losers and help them return to the labor market. But domestic economies may adjust too slowly to fully absorb those whose livelihoods have been affected by a trade agreement. Using the example of Mexican farmworkers displaced by NAFTA who could not find new jobs elsewhere, Thomas argues for explicitly linking trade-opening policies to concomitant policies on immigration, not only to reflect conceptual consistency but also to reflect norms of equality and equity as well as awareness of the social cost implications of trade in both the Global North and Global South.

\section{Toward a Progressive Agenda}

Here, we outline some elements for a progressive agenda and discuss ways that these ideas might be brought into the policy area.

\section{Measures for a progressive agenda}

Integrate trade and social policy

The first priority is to ensure that changes from trade create net benefits for society. To achieve that, we need to ensure that the disruption created by expanded trade will lead to significant gains, develop ways to minimize the negative social impact of trade agreements and provide adequate compensation for those who suffer losses. This would include measures to strengthen the rights of labor in exporting countries, impose penalties on countries that seek to gain market share by exploiting labor and ensure that losses in importing countries are adequately compensated. But progressives need to go further to ensure not only that losses in the North are compensated and labor conditions in the South improved but also that gains from trade are widely shared. We need to develop policies that will ensure not only that there are net gains but that they are widely shared in a rising tide that lifts all boats. Measures could include the following: 
- $\quad$ Requiring a social impact statement for trade agreements, including the views of groups that stand to lose

- Taxing trade winners and earmark receipts to compensate losers and redistribute gains, and create these mechanisms in international trade agreements

- Linking immigration and trade by including migration in trade agreements. Examples might include expanding commitments on Mode 4 (movement of natural persons) in services chapters, and reinforcing capacities for sector-by-sector reciprocal liberalization over time.

- Deterring races to the bottom by strengthening labor rights clauses and enabling social dumping remedies

- Focusing on other areas of trade law that affect workers beyond labor chapters, such as rules of origin, government procurement and investment chapters

- Using leverage during FTA negotiations to trigger domestic labor reform in both poor and rich countries

Tolerate diversity in economic models and facilitate economic development

Trade law functions best when it manages tensions between different ways to organize economies. Increased pressure for convergence erodes national sovereignty, deters experimentation and threatens democracy. At the most basic level, trade law should not penalize different economic models unless trade frictions cause serious harm. Further, it should facilitate, not deter, the search for better ways to achieve growth in the context of specific economies. Finally, trade law should not force changes that are deeply undemocratic: popular approval, if not the process for adopting such laws, at least should create an outer boundary for them. In the last three decades, trade law has tilted toward convergence to a single model of market economy, which has been presented as the only viable path to development despite strongly held views in many countries and solid evidence to the contrary. We need fewer restrictions on policy experimentation. Broadly speaking, challenges to alternative economic models and strategies should bear the burden of proof. Other measures could include

- A stronger concept of subsidiarity in WTO law in which national decisions are given priority 
- A new concept of fair trade that tolerates diversity

- A less restrictive subsidies agreement

- A revamped use of the industrial policy exemption

- Fewer limits on the operation of SOEs

- Fewer limits on capital controls

- Positive incentives for policy experimentation

Create a system for regulation of GVCs

Changes in the world economy render some traditional legal strategies obsolete. In GVCs, traditional labor law may have little effect. Buyer firms exercise disproportionate power. They secure most of the gains from exporting, thus limiting the growth potential for developing countries. Private governance systems fail to protect workers. Measures to deal with these conditions include

- A tax regime that ensures that the exporting countries get a fair share of rents

- Passport fees for firms that want to participate in the benefits of a FTA

- Trade law measures that impose responsibilities on buyer firms to ensure that fair labor standards are followed down the chain

- Meta regulation in trade agreements requiring national governments to deal more effectively with GVCs by creating rules that affect buyer firms and hold them responsible for fair labor practices

- Global, regional and bilateral monitoring of buyer firm and national government compliance

Make investment protection development friendly and socially progressive

Resistance to the BIT regime is growing as countries begin to realize its potential impact on important social policies and development objectives. Especially in the hands of arbitrators with probusiness approaches, protections like indirect expropriation can be used to limit policy space. Some FTAs have included a right to regulate covering environment, health and safety, but this does not go far enough. Investments, especially in infrastructure and mining, can have a 
disproportionate impact on local communities powerless to affect decisions. Measures could include

- Eliminating or severely circumscribing indirect expropriation

- Limiting the scope of the full protection and security guarantee

- Including an expansive Right to Regulate in treaties covering redistributive and industrial policy as well as environment, health and safety

- Providing protection in national foreign direct investment legislation instead of treaties

- Relying on state-to-state arbitration instead of investor-state dispute settlement

\section{Engaging with emergent progressive forces}

The goal of this book is threefold. We seek to elaborate a framework that can undergird a new and progressive approach to world trade and investment law, provide analysis of some of the more important issues now under discussion and make tentative suggestions for new policy initiatives. However, this book is just a beginning, and further steps need to be taken to fashion tools for action. These ideas should be elaborated in dialogue with other progressive forces. Real change will require engagement by interest groups, social movements, think tanks and policymakers in both the North and the South. We need to find ways to engage at those levels. We see that groups committed to work for a better and fairer globalization, such as the newly formed Progressive International led by Bernie Sanders and Yannis Varoufakis, are emerging: we look forward to engaging with them. 